\title{
Review \\ Cytokines as Biomarkers in Systemic Lupus Erythematosus: Value for Diagnosis and Drug Therapy
}

\author{
Helena Idborg ${ }^{1(\mathbb{D})}$ and Vilija Oke ${ }^{1,2, *}$ \\ 1 Division of Rheumatology, Department of Medicine, Karolinska Institutet, Karolinska University Hospital, \\ 17176 Stockholm, Sweden; helena.idborg@ki.se \\ 2 Center for Rheumatology, Academic Specialist Center, Stockholm Health Care Services, \\ 11365 Stockholm, Sweden \\ * Correspondence: vilija.oke@ki.se
}

Citation: Idborg, H.; Oke, V. Cytokines as Biomarkers in Systemic Lupus Erythematosus: Value for Diagnosis and Drug Therapy. Int. J. Mol. Sci. 2021, 22, 11327. https:// doi.org/10.3390/ijms222111327

Academic Editor: Trine N. Jorgensen

Received: 7 September 2021

Accepted: 13 October 2021

Published: 20 October 2021

Publisher's Note: MDPI stays neutral with regard to jurisdictional claims in published maps and institutional affiliations.

Copyright: (c) 2021 by the authors. Licensee MDPI, Basel, Switzerland. This article is an open access article distributed under the terms and conditions of the Creative Commons Attribution (CC BY) license (https:/ / creativecommons.org/licenses/by/ $4.0 /)$.

\begin{abstract}
Systemic Lupus Erythematosus (SLE) is a chronic autoimmune disease. The disease is characterized by activation and dysregulation of both the innate and the adaptive immune systems. The autoimmune response targets self-molecules including cell nuclei, double stranded DNA and other intra and extracellular structures. Multiple susceptibility genes within the immune system have been identified, as well as disturbances in different immune pathways. SLE may affect different organs and organ systems, and organ involvement is diverse among individuals. A universal understanding of pathophysiological mechanism of the disease, as well as directed therapies, are still missing. Cytokines are immunomodulating molecules produced by cells of the immune system. Interferons (IFNs) are a broad group of cytokines, primarily produced by the innate immune system. The IFN system has been observed to be dysregulated in SLE, and therefore IFNs have been extensively studied with a hope to understand the disease mechanisms and identify novel targeted therapies. In several autoimmune diseases identification and subsequent blockade of specific cytokines has led to successful therapies, for example tumor necrosis factor-alpha (TNF- $\alpha$ ) inhibition in rheumatoid arthritis. Authors of this review have sought corresponding developments in SLE. In the current review, we cover the actual knowledge on IFNs and other studied cytokines as biomarkers and treatment targets in SLE.
\end{abstract}

Keywords: lupus; systemic lupus erythematosus; SLE; biomarkers; cytokines; interferons

\section{Introduction}

Systemic lupus erythematosus (SLE) is a prototype of systemic autoimmune disease with a hallmark of autoantibody production against cell nuclei (antinuclear antibodies -ANA) and other intranuclear proteins including double stranded DNA (dsDNA). The disease may affect different organs and organ systems including skin, joints, kidney, the central and peripheral nervous systems. Hematological abnormalities, such as cytopenias and coagulation disturbances with associated risk for thromboembolic events are also common.

Activation of major components of the innate and adaptive immune systems are observed in patients with SLE. Increased levels of a range of cytokines are observed during the disease course [1]. Secreted cytokines can be observed in the circulation, saliva, urine and also identified in the target organ tissues such as skin, kidney and synovia. The majority of those cytokines have pro-inflammatory properties, but some have immunomodulatory or anti-inflammatory roles. Since the pathogenesis of the disease is not well understood, it is so far not clear if high levels of certain cytokines are driving the disease, or just an epiphenomenon to the malfunctioning immune regulation and responses, cell death or impaired clearance of unviable cell remnants.

A range of cytokines have been observed to correlate with SLE disease activity and proposed as therapeutic candidates for active SLE [1-3]. Cytokine blockade targeting TNF- 
$\alpha$ and IL-6, have been successfully developed to treat rheumatoid arthritis, while barely any anti-cytokine therapies have been successfully introduced into clinical practice as drugs for SLE patients. The discussed pitfall in SLE clinical trials has been the recruitment of heterogenous patient populations. It has therefore been suggested to stratify patients prior to recruitment to trials in regard to clinical and genetic phenotypes or cytokine profiles $[4,5]$.

A biomarker that aids the physician in decision making regarding diagnose and treatment would be a handy tool. Some investigators have suggested a definition of an ideal biomarker for SLE [6]. This biomarker should be specific, easy to detect, follow the disease activity, useful in follow-up and reasonably priced.

In the current review we will focus on recent advances and on evidence for the use of cytokines as biomarkers of SLE. If known, we will further discuss the role of cytokines in certain organ involvement. If available, we will include information on the outcomes of cytokine targeting therapies in clinical trials. The reviewed information on available knowledge of cytokine expression, association with disease activity and target organ involvement is presented in Table 1 . The cells that are the main cytokine sources are illustrated in Figure 1. In Table 2 we have summarized the data on recent clinical trials targeting cytokines for treatment of SLE.

Table 1. Overview of the cytokine regulation in the circulation, their correlation to disease activity, as well as association with and expression in the target organs of active SLE.

\begin{tabular}{|c|c|c|c|c|c|c|c|c|c|}
\hline \multirow{2}{*}{ Cytokine } & \multirow{2}{*}{ Immunity $^{1}$} & \multirow{2}{*}{$\begin{array}{c}\text { Levels in } \\
\text { Circulation }^{2}\end{array}$} & \multirow{2}{*}{ DAS $^{3}$} & \multicolumn{5}{|c|}{ SLE Target Organ Involvement ${ }^{4}$} & \multirow{2}{*}{$\begin{array}{l}\text { Where Cytokine Has } \\
\text { Been Detected }\end{array}$} \\
\hline & & & & LN & Arthritis & CLE & Serositis & CNS & \\
\hline IFN Type I & I & $\uparrow$ & + & $\uparrow$ & $\uparrow$ & $\uparrow$ & $\uparrow$ & $\uparrow$ & circulation \\
\hline IFN Type II & A & $\uparrow$ & + & $\uparrow$ & $\uparrow$ & $\uparrow$ & $\mathrm{NN}$ & $\mathrm{NN}$ & circulation \\
\hline IFN Type III & I & $\uparrow$ & + & $\uparrow$ & $\uparrow$ & $\uparrow$ & $\mathrm{NN}$ & $\mathrm{NN}$ & circulation, skin lesions \\
\hline BAFF/APRIL & I & $\uparrow$ & + & $\uparrow$ & $\uparrow$ & $\mathrm{NN}$ & $\mathrm{NN}$ & $\uparrow$ & circulation \\
\hline IL-2 & A & $\mathrm{NN}$ & $\mathrm{NN}$ & $\uparrow$ & $\mathrm{NN}$ & $\mathrm{NN}$ & $\mathrm{NN}$ & $\mathrm{NN}$ & renal tissue \\
\hline IL-6 & I & $\uparrow$ & + & $\uparrow$ & $\uparrow$ & $\uparrow$ & $\mathrm{NN}$ & $\uparrow$ & $\begin{array}{c}\text { circulation, CSF, urine, } \\
\text { serum }\end{array}$ \\
\hline IL-10 & I & $\uparrow$ & + & $\uparrow$ & $\mathrm{NN}$ & $\uparrow$ & $\mathrm{NN}$ & $\mathrm{NN}$ & circulation \\
\hline IL-16 & $\mathrm{A} / \mathrm{I}$ & $\uparrow$ & + & $\uparrow$ & $\mathrm{NN}$ & $\uparrow$ & $\mathrm{NN}$ & $\mathrm{NN}$ & $\begin{array}{l}\text { circulation, urine, skin } \\
\text { lesions }\end{array}$ \\
\hline IL-12, IL-23 & $\mathrm{A} / \mathrm{I}$ & $\uparrow$ & + & $\uparrow$ & $\mathrm{NN}$ & $\uparrow$ & $\mathrm{NN}$ & $\mathrm{NN}$ & circulation, kidney \\
\hline IL-17 & A & $\uparrow$ & + & $\uparrow$ & $\uparrow$ & $\uparrow$ & $\mathrm{NN}$ & $\mathrm{NN}$ & $\begin{array}{l}\text { circulation, kidney, skin, } \\
\text { synovial fluid }\end{array}$ \\
\hline IL-1 & I & $\uparrow$ & $\mathrm{NN}$ & $\uparrow$ & $\uparrow$ & $\uparrow$ & $\mathrm{NN}$ & $\mathrm{NN}$ & circulation, skin \\
\hline IL-18 & I & $\uparrow$ & + & $\uparrow$ & $\mathrm{NN}$ & $\uparrow$ & $\mathrm{NN}$ & $\mathrm{NN}$ & circulation, skin lesions \\
\hline IL-38 & I & $\uparrow$ & + & $\uparrow$ & $\uparrow$ & $\mathrm{NN}$ & $\uparrow$ & $\mathrm{NN}$ & circulation \\
\hline
\end{tabular}

1_Describes the cytokine's involvement in the immune system: I-the cytokine is a mediator of the innate immune system; A-the cytokine is a mediator of the adaptive immune system; ${ }^{2} \uparrow$-upregulated cytokine levels in circulation; ${ }^{3}$ DAS—disease activity score, + - cytokine is shown to be associated with DAS (SLAM or SLEDAI (SLEDAI-2K)); ${ }^{4}$ If known, we mention what active SLE manifestations have been demonstrated to be associated with each cytokine; IL-interleukin, LN-lupus nephritis, CLE-cutaneous lupus erythematosus, CNS — central nervous system, CSF—cerebrospinal fluid, BAFF—B cell activating factor, APRIL-a B cell proliferation-inducing ligand, $\mathrm{NN}-$ not known or data is uncertain. 
Table 2. Overview over registered therapies and ongoing trials on substances targeting cytokines as treatment targets for SLE (published or registered at www.clinicaltrials.gov, accessed on 10 October 2021. NCT number indicate registration number of clinical trial).

\begin{tabular}{|c|c|}
\hline Cytokine Target & Drug/Molecule and Results from Clinical Trials \\
\hline IFN Type I & $\begin{array}{l}\text { - Anifrolumab (MEDI 546), phase 3, primary endpoints met } \\
\text { NCT01753193, approved by FDA in 2021; and studied } \\
\text { post-registration NCT04877691. } \\
\text { - Lupuzor, IFNa kinoid (IFN-K), completed phase 2B } \\
\text { NCT01058343, secondary endpoints were met, ongoing } \\
\text { phase 3, NCT02665364 } \\
\text { - Sifalimumab MEDI-545, completed phase 2b, primary } \\
\text { putcome not met, NCT00979654. } \\
\text { - JNJ-55920839, Anti-IFN- } \alpha / \omega \text {, phase } 1 \text { ongoing, } \\
\text { NCT02609789. } \\
\text { Rontalizumab, primary endpoint was not met, phase } 2 \\
\text { NCT00962832 }\end{array}$ \\
\hline IFN Type II & $\begin{array}{l}\text { - } \quad \text { AMG } 811 \text { (anti-IFN-gamma), primary endoint not met, } \\
\text { - } \quad \text { Ehase 2, NCT02291588, NCT00818948 [7]. } \\
\text { recruitment }\end{array}$ \\
\hline IFN Type III & No trials identified \\
\hline $\begin{array}{l}\text { General IFN system: Target } \\
\text { plasmacytoid dendritic cells }\end{array}$ & $\begin{array}{l}\text { - daxdilimab VIB7734, phase 1, completed, results awaited } \\
\text { VIB7734 } \\
\text { BIIB059, primary endpoints met in phase } 2 \text { NCT02847598). } \\
\text { Phase } 3 \text { ongoing, NCT04895241 }\end{array}$ \\
\hline TNF- $\alpha$ & $\begin{array}{l}\text { - Infliximab, considered risky, investigated in open label } \\
\text { NCT00368264 [8]. }\end{array}$ \\
\hline Blys/BAFF/APRIL & $\begin{array}{l}\text { - } \quad \text { Benlysta, approved, postregistration studies ongoing } \\
\text { - } \quad \text { Ianalumab/OP0302 (VAY736) ongoing phase 2, } \\
\text { NCT03656562, results awaited. } \\
\text { - } \quad \text { Rozibafusp alfa (AMG 570), results awaited, phase 2, } \\
\text { NCT04058028 } \\
\text { - Tabalumab (LY 2127399), primary endpoints not met in } \\
\text { phase 3, NCT01196091 } \\
\text { - Atacicept, primary endpoints not met in phase 3, } \\
\text { NCT00624338 } \\
\text { Blisibimod (AMG 623/A-623), primary endpoints not met, } \\
\text { phase 3, NCT02443506 } \\
\text { Telitacicept, RC18, Phase 2, NCT02885610 }\end{array}$ \\
\hline IL-2 & $\begin{array}{l}\text { - } \quad \text { Recombinant Human Interleukin-2, positive results, Phase } \\
\text { 2\{He:2020cn\} NCT02465580 and NCT02932137 } \\
\text { - Several substances: NKTR-358 (LY3471851), ILT-101 and } \\
\text { more, Phase } 1 \text { and 2, NCT03556007, NCT04433585 }\end{array}$ \\
\hline
\end{tabular}


Table 2. Cont.

\begin{tabular}{|c|c|}
\hline Cytokine Target & Drug/Molecule and Results from Clinical Trials \\
\hline IL-6 & $\begin{array}{l}\text { - } \quad \text { MRA } 003 \text { US Ongoing phase } 1 \text { NCT00046774 } \\
\text { - } \quad \text { Ala-Cpn10 Ongoing phase } 1 \text { and } 2 \text { NCT01838694 } \\
\text { Vobarilizumab (ALX-0061) Completed phase 2, } \\
\text { NCT02437890 } \\
\text { - Sirukumab (CNTO 136) Completed phase 1, NCT01702740, } \\
\text { not further investigated } \\
\text { PF 04236921, completed phase 2, primary endpoint not met, } \\
\text { NCT01405196 }\end{array}$ \\
\hline IL-10 & BT 063, Phase 2 completed, results unavailable, NCT02554019 \\
\hline IL-16 & Not identified \\
\hline IL-17 & Sekucinumab, Phase 3 recruiting, NCT04181762 \\
\hline IL-12, IL-23 & $\begin{array}{l}\text { Ustekinumab, primary endpoints met in phase } 2 \mathrm{a} \text {, NCT02349061. } \\
\text { Phase } 3 \text { is ongoing, NCT03517722 }\end{array}$ \\
\hline IL-21 & $\begin{array}{l}\text { - } \quad \text { NNC0114-0006, Phase 1, NCT01689025 } \\
\text { BOS161721 (avizakimab). Completed phase } 1 \text { and 2, results } \\
\text { awaited NCT03371251 }\end{array}$ \\
\hline IL-1 & Anakinra, only case reports \\
\hline IL-18 & Not identified \\
\hline IL-38 & Not identified \\
\hline
\end{tabular}

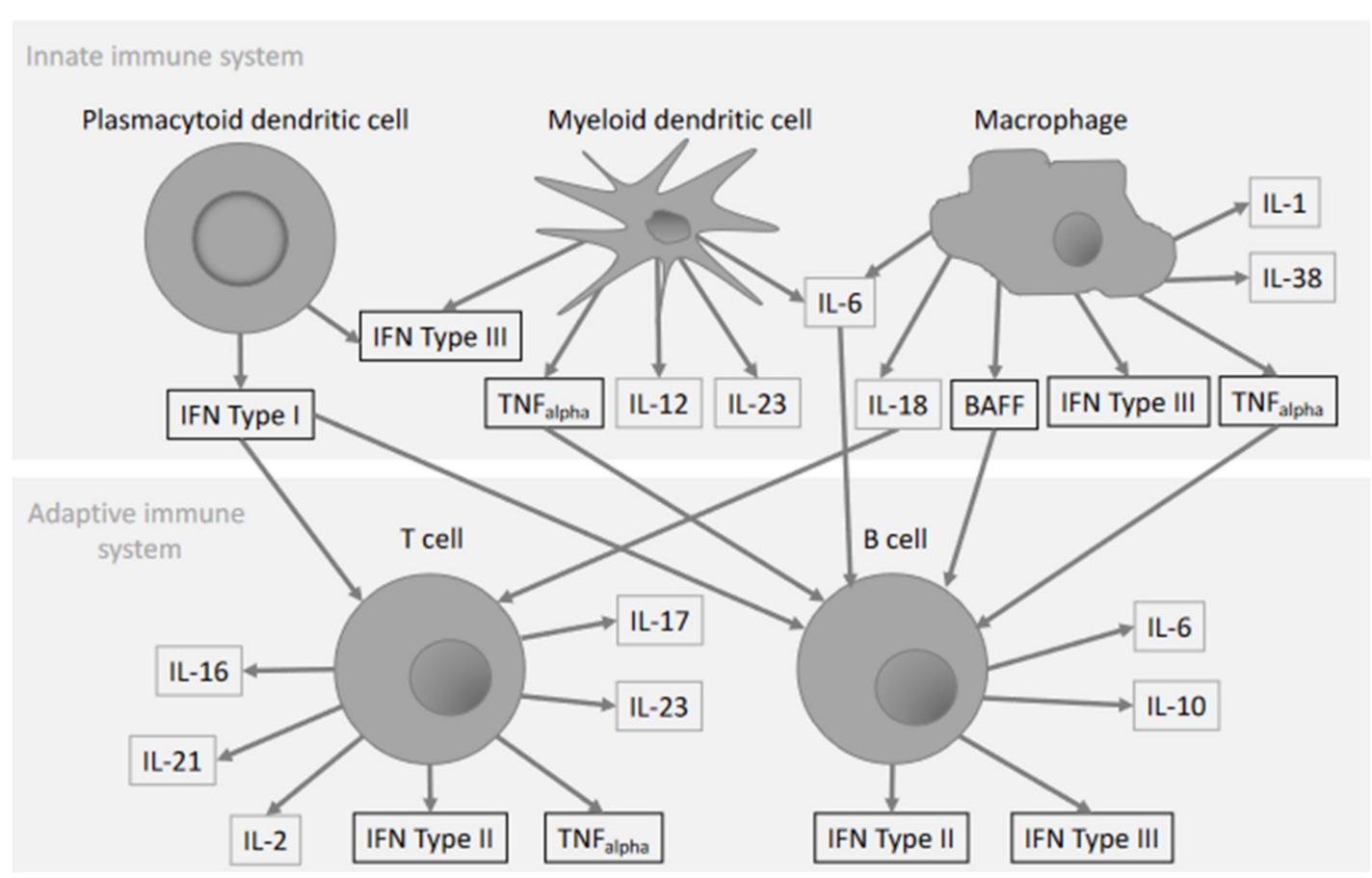

Figure 1. Cytokines associated with SLE pathogenesis are shown and arrows indicates the main producer or the main target cell.

\section{Interferons}

Interferons (IFNs) are pro-inflammatory cytokines produced in response to infections, as a part of the host defense by the innate immune system. In the human body, three types of IFNs are known to be produced and all seem to have role in SLE: type I, II and III. The type I IFNs include 17 subtypes of IFN- $\alpha$ s, also IFN- $\beta$, IFN- $\delta$, IFN- $\varepsilon$, IFN- $\kappa$, IFN- $\tau$, I FN- $\omega$ and IFN- $\zeta[2]$. 
The IFN- $\alpha$ s are the major effector cytokines of this type and it is the most studied in SLE. Knowledge on IFN- $\beta$ and IFN- $\kappa$ is also available, but other type I IFNs are less studied and considered of less importance [3,9].

All IFN- $\alpha$ s and single IFN- $\beta$ are ubiquitously expressed, while IFN- $\kappa$ is more organ specific [10]. The most potent type I IFNs producing cells are plasmacytoid dendritic cells $[1,4]$. All type I IFNs signal via same receptor denoted IFNAR1/IFNAR2 [2].

There is only one type II IFN-namely, IFN- $\gamma$-which is mainly produced by CD4+ or CD8+ Th1 lymphocytes, as well as NK and B cells, and also professional antigen presenting cells. The IFN- $\gamma$ signal is transmitted via receptor composed of two subunits IFNGR1 and IFNGR2 [9].

Four molecules, which belong to the type III IFN family, have been identified: IFN$\lambda 1,-\lambda 2,-\lambda 3$ and $-\lambda 4$. The main producers of IFN- $\lambda 1$ are antigen presenting cells, but also epithelial cells [10]. Epithelial and mucosal surfaces are the main responders and expressers of IFN $\lambda-1 R /$ IL10R [3].

\subsection{Type I IFNs in SLE}

\subsubsection{IFN- $\alpha$}

It was described already in 1990 that administration of IFN- $\alpha$ as a therapy for other diseases, can induce SLE [11]. Later on, upregulation of type I IFN signature has been discovered in SLE patients [12]. Ever since, type I IFNs have been a major focus of investigation as a diagnostic biomarker and therapeutic target for SLE $[10,13]$.

Detection and reliable measurements of IFN- $\alpha$ have been challenging due to its diversity, bio-degradability ex vivo and lack of specific detecting antibodies. Several methods have been used to study IFN- $\alpha$ in SLE: reporter cell assays, dissociation-enhanced lanthanide fluorescence immunoassay (DELFIA) [14], single-molecule-array (SIMOA) and enzyme-linked immunosorbent assay (ELISA) [15-18]. Recently, conventional ELISA techniques have been substantially improved and utilized in several studies $[5,18]$.

The classical method to measure serum induced type I IFN activity is by reporter cell assays (WISH cell line or healthy donor peripheral blood mononuclear cells (PBMCs)) [19]. These assays estimate how cells exposed to SLE patients' serum in vitro respond by upregulating IFN regulated genes. The most commonly assessed genes are MX Dynamin Like GTPase 1 (MX1), Protein kinase R (PKR) and Interferon Induced Protein With Tetratricopeptide Repeats 1 (IFIT1).

High serum induced type I IFN activity, as observed by WISH-reporter cell assay (IFN-activity), is defined as a heritable risk factor to develop SLE later in life [19]. High IFNactivity associate with SLE disease activity as observed in European and North American cohorts $[5,16,20]$. A certain auto-antibody profile has been coupled with high IFN-activity, including anti-dsDNA, anti-RNP, anti-Sm and anti-Ro autoAbs, rather than the antiphospholipid antibody profile (aPL) [20-22]. In our Karolinska SLE cohort high functional IFN-activity correlate positively with disease activity scores (both SLEDAI and SLAM) and, also with certain organ active involvement: e.g., nephritis, arthritis, lymphadenopathy, fatigue and weight loss [5]. The IFN-activity high group commonly have autoantibodies against dsDNA, nucleosome, Sm, SmRNP and RNP68; as well as demonstrate higher ESR and higher proteinuria, but lower hemoglobin, and WBC as well as PLT counts [5]. Photosensitivity and high disease damage associate negatively. High IFN-activity seems to be a feature of active younger patients early in the disease, since this parameter is associated with younger age, shorter disease duration and negatively correlated with disease damage index(SDI) in several studies [5].

Importantly, IFN-activity correlate with serum/plasma measurements of IFN- $\alpha$, IFN- $\gamma$ and IFN- $\lambda$. Therefore, we consider that IFN-activity could be an important, but less specific marker of activation of several IFN types in an active patient [4,5].

Dissociation-enhanced lanthanide fluorescence immunoassay (DELFIA) is another assay employed to measure the most the IFN- $\alpha$ subtypes (except IFN- $\alpha 2 b$ ) [4]. This method was used to measure IFN- $\alpha$ s in another Swedish cohort in 2000. The results demonstrated 
that all patients with rash, more than half of patients with lupus nephritis (LN) and two thirds with arthritis had upregulated serum levels of IFN- $\alpha$ [16]. IFN- $\alpha$ measurements were compared to serum induced IFN-activity in healthy donors (HD) PBMCs (SLE-HDIIF-activity). SLE-IIF-activity did not correlate with serum IFN- $\alpha$ measurements, and only white blood cell counts, and thrombocyte counts correlated negatively with both measurements [16]. Anti-dsDNA levels and decreasing complement levels correlated with IFN- $\alpha$ levels (Delphia), but not with SLE-HD-IIF $[14,16]$. In later studies, SLE-HD-IIF method has not been a method of choice.

A French group performed digital single-molecule-array (SIMOA) enzyme-linked immunoorbent assay (ELISA) to study IFN- $\alpha$ s in SLE [17]. In this cohort, high IFN- $\alpha$ levels associated with active disease which manifested as rash, low complement, and antiSm autoantibodies, and numerically (but non-significantly) increased in active nephritis. Interestingly, data demonstrated that the subgroup with active arthritis had significantly lower levels of IFN- $\alpha$ [17].

We employed a pan-IFN- $\alpha$ ELISA, which detects all IFN- $\alpha$ s (but not IFN- $\alpha 2 a$ and IFN$\alpha 12)$ to study IFN- $\alpha$ expression in Karolinska SLE cohort [5]. We found that in the cohort high IFN- $\alpha$ concentrations associated with mucocutaneous involvement, lymphadenopathy, low complement, positivity for Ro52/SSA, La/SSB, and lower occurrence of secondary antiphospholipid antibody syndrome and vascular events [5]. Patients with active LN had increased IFN- $\alpha$ levels which declined after therapy [23].

The available techniques for type I IFN detection are still relatively laborious and costly, and non-sufficiently reproducible. A study comparing IFN-activity, DELPHIA, SIMOA and ELISA methods in a substantial number of patients is needed in order to compare and validate all the methods.

In summary, levels of circulating IFN- $\alpha$ have been demonstrated to correlate with disease activity as estimated by SLEDAI, and anti-dsDNA levels and complement activation or consumption. Estimation of circulating IFN- $\alpha$ could potentially be used as a disease biomarker. So far it does not seem to have much additive value in comparison to traditionally assessed parameters such as SLEDAI, anti-ds-DNA or complement measurements, which are relatively cheap and available methods in most parts of the world. Therefore, these methods are mainly used in research. None of the type I IFN measuring methods have so far been introduced in routine clinical care, neither for diagnostic nor for prognostic purposes.

\subsubsection{IFN- $\beta$}

The majority of information on the role of IFN- $\beta$ in SLE comes from gene expression studies, where signatures of IFN- $\beta$ and IFN- $\alpha$ s partially overlap $[15,22]$. Data indicate that levels of IFN- $\beta$ and IFN- $\alpha$ overlap [21]. Detailed knowledge on which SLE manifestations or phenotypes, if any, are associated with high circulating IFN- $\beta$ levels remain to be studied. However, IFN- $\beta$ signals through the IFN- $\alpha$ receptor (IFNAR), therefore antiIFNAR therapies could most possibly block effects mediated by IFN- $\beta$ [22].

\subsubsection{IFN-K}

IFN- $\mathrm{K}$ is another member of the type I IFN-family, which is more limited to expression in certain tissues, e.g., in epithelial cells $[24,25]$. IFN $-\kappa$ has been demonstrated to be upregulated in Cutaneous lupus erythematosus (CLE) lesions after skin exposure to UVradiation [26]. Thus, IFN-k detection could be used by pathologists in lesion diagnostics, but otherwise it is probably less suitable as disease biomarker for routine use since a skin biopsy is needed in order to assess its expression. IFN-k could potentially serve as a treatment target for CLE, especially if a topical anti-IFN-K treatment can be developed.

\subsection{IFN Type II in SLE}

It was described over thirty years ago that exogenously infused IFN- $\gamma$ had the ability to induce SLE or exacerbate SLE flares $[24,27]$. Focus on IFN- $\gamma$ in SLE has been limited, but 
several recent reports have demonstrated the importance of this mediator in SLE [20,28]. Importantly, levels of IFN- $\gamma$ increase in parallel to autoantibody development, years before activation of type I IFNs and clinically manifest SLE [25]. Interest in IFN- $\gamma$ increased recently due to two reasons: unsuccessful clinical trials on type I IFN-blockade and also demonstration that signature of type I, II and III IFNs overlap [25]. We and others have identified that levels of IFN- $\gamma$ correlate with IFN-activity, as measured by cell reporter assays in vitro. In the Karolinska SLE cohort, high IFN- $\gamma$ was associated with high SLEDAI scores, active arthritis, complement consumption and positivity for anti-Ro60/SSA [20,28]. Interestingly, mycobacterium tuberculosis IFN- $\gamma$ release assay (TB-IGRA) could demonstrate spontaneous IFN- $\gamma$ release (SIR) in the SLE cohort. Normalized TB-IGRA values correlated with disease activity better than anti-dsDNA or complement levels, and were associated with cutaneous disease, hypocomplementemia, fever and thrombocytopenia [29]. SIR estimated by TB-IGRA test has been suggested as SLE biomarker by the investigators [29].

In summary, recent data indicate that IFN- $\gamma$ levels incline before developing SLE symptoms and high circulating levels are associated with more severe SLE. SIR, assessed by TB-IGRA test, should be further explored as a disease biomarker. Direct or indirect medications targeting IFN- $\gamma$ pathway are of further interest in drug development.

\subsection{IFN Type III in SLE}

The role of type III IFNs, including four subtypes of IFN- $\lambda 1,-2,-3$ and -4 , has been identified during the recent years. IFN- $\lambda \mathrm{s}$ are easier to study since they may be detected in circulation by conventional ELISAs or by immunohistochemistry. Levels of IFN- $\lambda 3$ have been reported to correlate with SLE disease activity, active LN and arthritis, and complement consumption $[28,30,31]$. IFN- $\lambda 1$ is upregulated locally at the site of inflammation in CLE skin and LN renal lesions [23,30,32]. Levels of IFN- $\alpha$ and IFN- $\lambda 1$ were measured in the Karolinska LN cohort before and after induction therapy for LN [23]. Overall levels of IFN- $\alpha$ s decreased after therapy, but levels of IFN- $\lambda 1$ decreased only in patients who responded to therapy, while they remained high in histological non-responders. Data from this study indicate that high IFN- $\lambda 1$ levels in patients who did not respond to therapy could be a biomarker of therapy resistant LN. However, this data should be replicated and validated.

In our cohort, we also noted that high IFN- $\lambda 1$ levels are a feature of patients with cardiovascular events, secondary antiphospholipid syndrome (APS) and often associated warfarin treatment. High IFN- $\lambda 1$ with co-upregulation of Th17 cytokines identified patients with renal damage [18].

\section{IFNs as Treatment Targets in SLE}

\subsection{IFNs Type I Targeting Therapy}

Blockade of type I IFNs has been suggested to be a promising treatment approach for SLE. Treatment modalities included either blockade of circulating IFNs or blocking of the IFN- $\alpha$ receptor.

Several pharmaceutical companies developed anti-type I IFN monoclonal antibodies that have been tested in phase 2 and 3 clinical trials [22,33] (Table 2). The selected patient groups were active SLE without life-threatening disease manifestations on stable "standard of care" therapies and fixed steroid doses. The typical patient recruited for the studies had a SLEDAI score of 6 or higher, was positive for anti-dsDNA antibodies and had low complement levels. The clinical manifestations were dominated by cutaneous, articular or hematological symptoms, or serological findings. However, none of the studies reached primary endpoints [22,33].

Anifrolumab, a type I interferon receptor antagonist, was designed to block signaling of all type I IFNs [22]. In clinical trials, anifrolumab treatment was demonstrated to be beneficial in moderate to severe treatment resistant non-renal SLE, and furthermore it neutralized the IFN-signature in those patients who were high at recruitment [34]. Anifrolumab has recently got approved by United States Food and Drug Administration 
(FDA) for treatment of moderately severe SLE and is further studied both in the trials and real life [22,35].

\subsection{IFN- $\gamma$ Targeting Therapy}

Anti-IFN- $\gamma$ therapy was tested in SLE patients with or without nephritis and also with a discoid form of cutaneous lupus erythematosus [7,36]. Unfortunately, effects of the therapy were less pronounced and not sustained in the subjects. Also, a majority of the patients reported adverse events [7,36]. Direct targeting of IFN- $\gamma$ does not seem to be a suitable treatment approach. Levels of IFN- $\gamma$ can be modulated via other mechanisms. Interestingly, in the Phase II clinical trial of ustekinumab in SLE, the responders had declining IFN- $\gamma$ levels, and this finding was suggested as a biomarker of response to anti (IL-12)/IL-23 p40 therapy [37].

\subsection{IFN- $\lambda$ Targeting Therapy}

No studies directly targeting IFN- $\lambda$ were registered at www.clinicaltrial.gov (accessed on 10 May 2021).

\section{TNF- $\alpha$}

Tumor necrosis factor $\alpha$ (TNF- $\alpha$ ) is a major cytokine secreted by macrophages upon the cell encountering a pathogen. Abnormally high TNF- $\alpha$ production is observed in several autoimmune diseases including SLE. TNF- $\alpha$ can either promote or modulate autoimmunity [38]. TNF- $\alpha$ has been shown to be upregulated in SLE patients compared to healthy controls and circulating levels of TNF- $\alpha$ have been shown to correlate with disease activity [39-41]. High levels of circulating TNF- $\alpha$ associate with active renal, articular, and neuropsychiatric manifestations such as mood and anxiety disorders, but was not significantly different with regard to active CLE [41,42]. However, TNF- $\alpha$ is upregulated in CLE lesions and its expression levels in the tissue correlate with the development and healing of UV-induced lesions [42,43].

In our Karolinska SLE cohort we found that ratio of TNF- $\alpha$ and serum albumin levels were the best discriminators between patients and controls, in particular those with renal involvement [40]. There is now a consensus that high levels of circulating TNF- $\alpha$ are associated with SLE and might be a useful biomarker [13].

Attempts to block TNF- $\alpha$ in SLE were not as successful as in rheumatoid arthritis and resulted in exacerbations of the disease as reviewed by De Bandt [44]. Therefore, the rationale and evidence for TNF-blockade in SLE were reviewed as a double-edged sword [8]. Some authors consider that TNF blockade might still be beneficial in a subset of patients. According to the case reports, anti-TNF therapy seems to have a positive effect in targeting lupus arthritis, and it seems not to induce nephritis, but rather autoantibodies and rash [8]. Interestingly, data show that the mode of action of the commonly used antimalarial drugs is partly via suppressing both TNF- $\alpha$ and IFN- $\alpha$ levels $[45,46]$. Today, the use of TNF-blockade in SLE is still limited and not recommended as treatment due to risks.

\section{BAFF/APRIL}

B cell activating factor (BAFF), also known as B lymphocyte stimulator (BLyS), and A proliferation-inducing ligand (APRIL) are members of the TNF superfamily and the role of the BAFF/APRIL system in SLE has been reviewed in detail before $[47,48]$. BAFF are increased in patients with SLE and have been reported to predict flares [49]. Several, but not all studies demonstrated correlation between serum levels of BAFF/APRIL and disease activity, as measured by the British Isles Lupus Assessment Group (BILAG) index [50] and SLEDAI [47,48]. Possibly high levels of BAFF/APRIL are more strongly linked to specific organ involvements, such as arthritis, neurologic manifestations or renal disease [48]. Studies of these biomarkers in urine are limited, although elevated levels of BAFF in urine have been detected in a fraction of patients with lupus nephritis [51]. 
Belimumab, a BAFF inhibitor, was approved for SLE indication in 2011. It is the only biological drug approved for treatment of SLE patients so far [52]. Belimumab is a monoclonal antibody that inhibits BAFF and it has been demonstrated to reduce disease activity and prevent organ damage in SLE [53,54]. Novel treatment approaches of SLE have recently been reviewed, and while Belimumab is approved, Atacicept, a combined BAFF/APRIL inhibitor [55], is being further studied in phase II/III clinical trials [56].

Serum levels of both BAFF and APRIL have been suggested as biomarkers for treatment response to atacicept [57]. However, levels of circulating BAFF and APRIL could be affected differently by immunosuppressive drugs, e.g., APRIL can decrease while BAFF can be unchanged during treatment [58]. This discrepancy should be further explored.

\section{IL-2}

Interleukin-2 is a pleiotropic cytokine that plays multiple functions in $\mathrm{T}$ cell homeostasis and differentiation. It is mainly produced by activated CD4+ and CD8+ cells. IL-2 has a role in T cell pathogen recognition and discrimination between "foreign and self" [59].

Impaired production of IL-2 has been observed in SLE, and IL-2 deficiency was associated with renal impairment [60]. Interestingly, SLE patients may produce anti-IL-2 autoantibodies, which have been associated with disease activity [61].

Low dose treatment with IL-2 has been tested as a therapy for active SLE in a limited number of patients. The trial did not meet the primary endpoint, i.e., did not reduce disease activity; however, significantly more nephritis patients reached remission in the IL-2, as compared to the placebo arm [62]. Further studies are needed to investigate potential benefit of IL-2 reconstitution in SLE.

\section{IL-6}

Interleukin-6 is a pro-inflammatory cytokine upregulated in several systemic autoimmune diseases including SLE [63]. Some studies demonstrated that plasma levels of IL-6 correlate to SLE disease activity, but other investigators could not confirm these findings. Interleukin-6 reflects the cytokine-mediated inflammation, which is not always followed by activation of complement. The latter is an important item in several measures of SLE disease activity, including SLEDAI [64]. Upregulated plasma levels of IL-6 have been observed in patients with kidney damage [39,40]. In a recent review, IL-6 was suggested as an important mediator in lupus nephritis [65], and urinary IL-6 has also been suggested as a marker for it [53,54].

Tocilizumab is a monoclonal antibody that inhibits IL-6 signaling and its efficacy in SLE patients was first evaluated in 2010 [66]. Tocilizumab therapy may be efficient in subgroups of patients with high inflammatory activity, although cautions must be taken since high doses may result in immunosuppression [67]. So far, no IL-6 targeting therapies have been approved for treatment of SLE.

\section{IL-10}

IL-10 is an anti-inflammatory cytokine, but it also has pro-inflammatory properties that might be mediated by type I IFNs [68]. Its role in the pathogenesis of SLE is complex. Variations in IL-10 gene are associated with risk for SLE [13,69]. Plasma levels of IL-10 are increased in SLE patients compared to controls [40], and some studies show correlation to disease activity or to levels of anti-dsDNA antibodies [51,60,61].

A trial with anti-IL-10 monoclonal antibody demonstrated reduced disease activity in SLE patients, although patients developed anti-drug antibodies and long-term treatment must be further studied [70]. A phase IIa clinical trial of an anti-IL-10 monoclonal antibody (BT063) the primary endpoint was achieved according to the company 2020 [71].

\section{IL-16}

Interleukin-16 is a cytokine, produced by T cells, epithelial cells and Langerhans cells. IL-16 is produced as a precursor molecule, which must be cleaved by caspase-3 to become 
activated. Interestingly, this mechanism, despite caspase-3 activation, does not necessarily induce cell apoptosis [72]. The generated product is a mature secretory IL-16 and has CD4 and CD9 as ligands. The secreted IL-16 mediates CD4+ T cell chemotaxis and functions as $\mathrm{T}$ cell growth factor, while cleaved pro-IL-16 mediates cell functions within the cell nuclei and inhibits cell cycle progression [73]. Interleukin-16 has been demonstrated as a promoting mediator of several cancers [73].

High levels of IL-16 in active SLE patients were described over 20 years ago [74]. Recently, our group reported results from a Mesoscale Discovery (MSD) multiplex analysis of circulating cytokines in SLE patients [40]. Among 30 tested cytokines, IL-16 was identified among the top five and increased concentrations in the circulation were found in patients with active nephritis. Also, in another unbiased analysis of cutaneous proteome of CLE lesions, IL-16 was identified as the only cytokine differentially upregulated in CLE in comparison to dermatomyositis (DM) [75]. These findings encourage further studies on the IL-16 role in SLE.

\section{IL-12, IL-17 and IL-23}

Interleukin-12 is a bridging cytokine between innate and adaptive immune systems, composed of a dimer entitled p40 and p70 and is secreted mainly by dendritic cells upon their stimulation by microbial antigens. Importantly, the p40 subunit is shared with IL-23. Interleukin-12 in parallel to IFN- $\gamma$ divert T cell development towards Th1 response. SLE patients have increased levels circulating of IL-12p40 subunit, which correlate positively to disease activity and associate negatively with complement C3 levels [6,71].

Interleukin-23 is the cytokine produced by antigen presenting cells which diverts CD4+ cell development towards Th17 phenotype. Interleukin-23 is comprised of p19 and p40, the latter shared with IL-12. The IL-17 cytokine family consists of six related proteins IL-17A, B, C, D, E and F. IL-17 is mainly produced by Th17 cells, but also by, $\gamma \delta-T$ cells, some natural killer T (NKT) cells and TCR $\beta+$ or so called 'natural' Th17 cells [76]. The major biological role of IL-17 is protection against fungal and bacterial infections, but it also has a protective role in intestinal barrier integrity. Interestingly, besides IL-17, Th-17 cells also produce IFN- $\lambda 1$, and together these molecules provide protection from pathogens on the skin surface [77]. Several studies reported that the majority of SLE patients have increased levels of IL-17A and IL-17F [78,79].

Levels of circulating IL-17A have been found to correlate with the Cutaneous Lupus Erythematosus activity and damage score index (CLASI) score [79], and high IL-17A expression has been demonstrated in the cellular infiltrates of the skin tissue of CLE lesions [80], as well as in kidneys affected by lupus nephritis (LN) [48]. High IL-17A levels at baseline predicted poor response to LN therapy [78] and deteriorating kidney function, if paralleled by INF- $\lambda 1$ and IL-23 [18]. Also, persistently high levels of IL-23 were detected in non-responding lupus nephritis patients [78]. Increased levels of IL-17A in parallel to high IL-6 expression were found in synovial fluid derived from patients with active lupus arthritis, the same cells, when stimulated, could produce high amounts of IFN- $\gamma$ [81].

Several investigators suggested that targeting IL-12, IL-23, and IL-17 could be a therapeutic option in SLE, since modulation of this pathway may also have regulatory effect on the IFN system via indirect mechanisms [82]. This hypothesis is under investigation. Ustekinumab, antagonist of p40, shared by IL-12 and IL-23, was studied in a phase 2 trial as an add-on therapy to standard of care. The study has demonstrated positive effects on clinical and laboratory parameters of SLE - namely, cutaneous and articular manifestations-with a good safety profile. The responders had declining IFN- $\gamma$ levels [83]. The results of long-term outcomes are awaited.

\section{IL-1, IL-18 and IL-38}

The interleukin- 1 cytokine superfamily includes several molecules: IL-1 $\alpha$, IL-1 $\beta$, IL-18, IL-33 and IL-38. The IL-1 system is a part of the innate immune system and operates via inflammasome as a primary response of pathogen recognition. Several investigators found 
that peripheral levels of IL-1 $\alpha$ were in the same range as in controls. In the Karolinska SLE cohort, however, high IL-1 $\alpha$ levels were observed in patients with renal and articular manifestations [40]. Increased levels of tissue IL-1 $\beta$ were found in the skin of photoprovoked developing CLE lesions. This was accompanied by increased TNF- $\alpha$ and HMGB1 expression [42].

Interleukin-18 is a cytokine secreted mainly by macrophages and has an effect on IFN- $\gamma$ production by Th1 cells and splenocytes, and may act in synergy with IL-12, another IFN- $\gamma$-inducible cytokine [84]. High serum levels of IL-18 are found in SLE patients, and particularly patients with active renal disease who were prone to develop renal damage at the follow-up [85]. High IL-18 expression is also observed in CLE lesions [86]. A recent metanalysis proposed IL-18 as a biomarker for active SLE [87]. In mouse models, blockade of IL-18 delays onset of the SLE-like autoimmunity and this approach is worth further exploration in humans [84].

IL-38 has been relatively recently studied in SLE. The levels of this cytokine were higher in active patients and associated with multiple clinical and laboratory parameters including arthritis, pericarditis, haematuria, proteinuria, pyuria and anti-dsDNA. Correlation analysis indicated that plasma IL-38 correlated positively with SLEDAI and negatively with C3 and C4 levels [88].

\section{IL-21}

Interleukin-21 (IL-21) is an autocrine cytokine mainly produced by follicular helper $\mathrm{T}$ (Tfh) and T helper 17 (Th17) cells. It has a role in the development of Tfh and Th17 cells, but also differentiation of B cells into plasma cells mediated by several biological pathways, including JAK/STAT [89]. Single-nucleotide polymorphisms in IL-21 and its receptor (IL-21R) have been associated with susceptibility to SLE. Increased amounts of IL-21 positive cells were reported in SLE patient circulation [90]. Other investigators found reduced levels of circulating IL-21 in SLE patients [91]. Data indicate that locally secreted IL-21 could facilitate development of autoreactive B-cells [92]. Molecules targeting IL-21 are currently tested in clinical trials for treatment of SLE (Table 2).

\section{Conclusions}

To conclude, available data demonstrate that SLE is a complex autoimmune disease and details of the underlying disease mechanisms remain to be understood. Multiple cytokines from different cytokine networks are elevated in SLE. However, data indicate that different manifestations or SLE phenotypes are associated with different cytokine networks and patterns. Thus, no single perfect disease biomarker has been identified so far. Benefits of the available cytokine targeting therapies are still limited. Available evidence indicates that different SLE phenotypes are associated with diverse cytokine networks and patient subgroups will require tailored therapies. More detailed disease phenotyping would be helpful when planning therapeutic trials and tailoring personalized treatment.

Author Contributions: H.I. and V.O. contributed equally to writing this review. All authors have read and agreed to the published version of the manuscript.

Funding: This work was funded by King Gustaf V's 80-year foundation, Karolinska Institutets Research foundation, Swedish Rheumatism Association, Signe and Reinhold Sunds Foundation.

Acknowledgments: Elisabet Svenungsson, Karolinska University Hospital is acknowledged for reviewing this work and contributing with valuable comments.

Conflicts of Interest: The authors declare no conflict of interest.

\section{References}

1. La Cava, A. Anticytokine therapies in systemic lupus erythematosus. Immunotherapy 2010, 2, 575-582. [CrossRef] [PubMed]

2. Rönnblom, L.; Leonard, D. Interferon pathway in SLE: One key to unlocking the mystery of the disease. Lupus Sci. Med. 2019, 6, e000270. [CrossRef] [PubMed] 
3. Chasset, F.; Arnaud, L. Targeting interferons and their pathways in systemic lupus erythematosus. Autoimmun. Rev. 2018, 17, 44-52. [CrossRef] [PubMed]

4. Touma, Z.; Sayani, A.; Pineau, C.A.; Fortin, I.; Matsos, M.; Ecker, G.A.; Chow, A.; Iczkovitz, S. Belimumab use, clinical outcomes and glucocorticoid reduction in patients with systemic lupus erythematosus receiving belimumab in clinical practice settings: Results from the OBSErve Canada Study. Rheumatol. Int. 2017, 37, 865-873. [CrossRef] [PubMed]

5. Oke, V.; Gunnarsson, I.; Dorschner, J.; Eketjäll, S.; Zickert, A.; Niewold, T.B.; Svenungsson, E. High levels of circulating interferons type I, type II and type III associate with distinct clinical features of active systemic lupus erythematosus. Arthritis Res. Ther. 2019, 21, 107. [CrossRef] [PubMed]

6. Aragón, C.C.; Tafúr, R.-A.; Suárez-Avellaneda, A.; Martínez, M.T.; de Salas, A.L.; Tobón, G.J. Urinary biomarkers in lupus nephritis. J. Transl. Autoimmun. 2020, 3, 100042. [CrossRef]

7. Boedigheimer, M.J.; Martin, D.A.; Amoura, Z.; Sánchez-Guerrero, J.; Romero-Diaz, J.; Kivitz, A.; Aranow, C.; Chan, T.M.; Chong, Y.B.; Chiu, K.; et al. Safety, pharmacokinetics and pharmacodynamics of AMG 811, an anti-interferon- $\gamma$ monoclonal antibody, in SLE subjects without or with lupus nephritis. Lupus Sci. Med. 2017, 4, e000226. [CrossRef]

8. Aringer, M.; Smolen, J.S. Therapeutic blockade of TNF in patients with SLE-promising or crazy? Autoimmun. Rev. 2012, 11, 321-325. [CrossRef]

9. Schroder, K.; Hertzog, P.J.; Ravasi, T.; Hume, D.A. Interferon-gamma: An overview of signals, mechanisms and functions. J. Leukoc. Biol. 2004, 75, 163-189. [CrossRef]

10. Crow, M.K.; Rönnblom, L. Type I interferons in host defence and inflammatory diseases. Lupus Sci. Med. 2019, 6, e000336. [CrossRef]

11. Rönnblom, L.E.; Alm, G.V.; Oberg, K.E. Possible induction of systemic lupus erythematosus by interferon-alpha treatment in a patient with a malignant carcinoid tumour. J. Intern. Med. 1990, 227, 207-210. [CrossRef]

12. Baechler, E.C.; Batliwalla, F.M.; Karypis, G.; Gaffney, P.M.; Ortmann, W.A.; Espe, K.J.; Shark, K.B.; Grande, W.J.; Hughes, K.M.; Kapur, V.; et al. Interferon-inducible gene expression signature in peripheral blood cells of patients with severe lupus. Proc. Natl. Acad. Sci. USA 2003, 100, 2610-2615. [CrossRef] [PubMed]

13. Rönnblom, L.; Elkon, K.B. Cytokines as therapeutic targets in SLE. Nat. Rev. Rheumatol. 2010, 6, 339-347. [CrossRef] [PubMed]

14. Rönnblom, L.E.; Perers, A.; Vallin, H.S.; Eriksson, I.; Osterlind, A.; Cederblad, B.; Alm, G. Detection of serum interferon-alpha by dissociation-enhanced lanthanide fluoroimmunoassay. Studies of patients with acute viral and bacterial infections. APMIS 1997, 105, 531-536. [CrossRef] [PubMed]

15. Hua, J.; Kirou, K.; Lee, C.; Crow, M.K. Functional assay of type I interferon in systemic lupus erythematosus plasma and association with anti-RNA binding protein autoantibodies. Arthritis Rheum. 2006, 54, 1906-1916. [CrossRef]

16. Bengtsson, A.A.; Sturfelt, G.; Truedsson, L.; Blomberg, J.; Alm, G.; Vallin, H.; Rönnblom, L. Activation of type I interferon system in systemic lupus erythematosus correlates with disease activity but not with antiretroviral antibodies. Lupus 2000, 9, 664-671. [CrossRef]

17. Mathian, A.; Mouries-Martin, S.; Dorgham, K.; Devilliers, H.; Barnabei, L.; Ben Salah, E.; Cohen-Aubart, F.; Garrido Castillo, L.; Haroche, J.; Hie, M.; et al. Monitoring disease activity in systemic lupus erythematosus with single-molecule array digital ELISA quantification of serum interferon- $\alpha$. Arthritis Rheumatol. 2018, 71, 759-765.

18. Oke, V.; Brauner, S.; Larsson, A.; Gustafsson, J.; Zickert, A.; Gunnarsson, I.; Svenungsson, E. IFN- $\lambda 1$ with Th17 axis cytokines and IFN- $\alpha$ define different subsets in systemic lupus erythematosus (SLE). Arthritis Res. Ther. 2017, 19, 139. [CrossRef]

19. Niewold, T.B.; Hua, J.; Lehman, T.J.A.; Harley, J.B.; Crow, M.K. High serum IFN-alpha activity is a heritable risk factor for systemic lupus erythematosus. Genes Immun. 2007, 8, 492-502. [CrossRef]

20. Weckerle, C.E.; Franek, B.S.; Kelly, J.A.; Kumabe, M.; Mikolaitis, R.A.; Green, S.L.; Utset, T.O.; Jolly, M.; James, J.A.; Harley, J.B.; et al. Network analysis of associations between serum interferon- $\alpha$ activity, autoantibodies, and clinical features in systemic lupus erythematosus. Arthritis Rheum. 2011, 63, 1044-1053. [CrossRef]

21. Paradowska-Gorycka, A.; Wajda, A.; Stypinska, B.; Walczuk, E.; Rzeszotarska, E.; Walczyk, M.; Haladyj, E.; RomanowskaProchnicka, K.; Felis-Giemza, A.; Lewandowska, A.; et al. Variety of endosomal TLRs and Interferons (IFN- $\alpha$, IFN- $\beta$, IFN- $\gamma$ ) expression profiles in patients with SLE, SSc and MCTD. Clin. Exp. Immunol. 2021, 204, 49-63. [CrossRef]

22. Furie, R.; Khamashta, M.; Merrill, J.T.; Werth, V.P.; Kalunian, K.; Brohawn, P.; Illei, G.G.; Drappa, J.; Wang, L.; Yoo, S.; et al. Anifrolumab, an Anti-Interferon- $\alpha$ Receptor Monoclonal Antibody, in Moderate-to-Severe Systemic Lupus Erythematosus. Arthritis Rheumatol. 2017, 69, 376-386. [CrossRef]

23. Zickert, A.; Oke, V.; Parodis, I.; Svenungsson, E.; Sundström, Y.; Gunnarsson, I. Interferon (IFN)- $\lambda$ is a potential mediator in lupus nephritis. Lupus Sci. Med. 2016, 3, e000170. [CrossRef]

24. Graninger, W.B.; Hassfeld, W.; Pesau, B.B.; Machold, K.P.; Zielinski, C.C.; Smolen, J.S. Induction of systemic lupus erythematosus by interferon-gamma in a patient with rheumatoid arthritis. J. Rheumatol. 1991, 18, 1621-1622. [PubMed]

25. Munroe, M.E.; Lu, R.; Zhao, Y.D.; Fife, D.A.; Robertson, J.M.; Guthridge, J.M.; Niewold, T.B.; Tsokos, G.C.; Keith, M.P.; Harley, J.B.; et al. Altered type II interferon precedes autoantibody accrual and elevated type I interferon activity prior to systemic lupus erythematosus classification. Ann. Rheum. Dis. 2016, 75, 2014-2021. [CrossRef] [PubMed]

26. Sarkar, M.K.; Hile, G.A.; Tsoi, L.C.; Xing, X.; Liu, J.; Liang, Y.; Berthier, C.C.; Swindell, W.R.; Patrick, M.T.; Shao, S.; et al Photosensitivity and type I IFN responses in cutaneous lupus are driven by epidermal-derived interferon kappa. Ann. Rheum. Dis. 2018, 77, 1653-1664. [CrossRef] [PubMed] 
27. Machold, K.P.; Smolen, J.S. Interferon-gamma induced exacerbation of systemic lupus erythematosus. J. Rheumatol. 1990, 17, 831-832. [PubMed]

28. Amezcua-Guerra, L.M.; Márquez-Velasco, R.; Chávez-Rueda, A.K.; Castillo-Martínez, D.; Massó, F.; Páez, A.; Colín-Fuentes, J.; Bojalil, R. Type III Interferons in Systemic Lupus Erythematosus: Association Between Interferon $\lambda 3$, Disease Activity, and Anti-Ro/SSA Antibodies. J. Clin. Rheumatol. 2017, 23, 368-375. [CrossRef] [PubMed]

29. Thomason, J.L.; Obih, U.M.; Koelle, D.M.; Lood, C.; Hughes, A.G. An interferon-gamma release assay as a novel biomarker in systemic lupus erythematosus. Rheumatology 2020, 59, 3479-3487. [CrossRef]

30. Chen, J.-Y.; Wang, C.-M.; Chen, T.-D.; Jan Wu, Y.-J.; Lin, J.-C.; Lu, L.Y.; Wu, J. Interferon- $\lambda 3 / 4$ genetic variants and interferon- $\lambda 3$ serum levels are biomarkers of lupus nephritis and disease activity in Taiwanese. Arthritis Res. Ther. 2018, 20, 193. [CrossRef]

31. Wu, Q.; Yang, Q.; Lourenco, E.; Sun, H.; Zhang, Y. Interferon-lambda1 induces peripheral blood mononuclear cell-derived chemokines secretion in patients with systemic lupus erythematosus: Its correlation with disease activity. Arthritis Res. Ther. 2011, 13, R88. [CrossRef]

32. Zahn, S.; Rehkämper, C.; Kümmerer, B.M.; Ferring-Schmidt, S.; Bieber, T.; Tüting, T.; Wenzel, J. Evidence for a pathophysiological role of keratinocyte-derived type III interferon (IFN $\lambda$ ) in cutaneous lupus erythematosus. J. Investig. Dermatol. 2011, 131, 133-140. [CrossRef] [PubMed]

33. Khamashta, M.; Merrill, J.T.; Werth, V.P.; Furie, R.; Kalunian, K.; Illei, G.G.; Drappa, J.; Wang, L.; Greth, W.; CD1067 Study Investigators. Sifalimumab, an anti-interferon- $\alpha$ monoclonal antibody, in moderate to severe systemic lupus erythematosus: A randomised, double-blind, placebo-controlled study. Ann. Rheum. Dis. 2016, 75, 1909-1916. [CrossRef]

34. Chatham, W.W.; Furie, R.; Saxena, A.; Brohawn, P.; Schwetje, E.; Abreu, G.; Tummala, R. Long-Term Safety and Efficacy of Anifrolumab in Adults With Systemic Lupus Erythematosus: Results of a Phase II Open-Label Extension Study. Arthritis Rheumatol. 2021, 73, 816-825. [CrossRef]

35. FDA Approves AstraZeneca's Anifrolumab for Lupus. Available online: https://www.nature.com/articles/d41573-021-00139-y (accessed on 6 August 2021).

36. Werth, V.P.; Fiorentino, D.; Sullivan, B.A.; Boedigheimer, M.J.; Chiu, K.; Wang, C.; Arnold, G.E.; Damore, M.A.; Bigler, J.; Welcher, A.A.; et al. Brief Report: Pharmacodynamics, Safety, and Clinical Efficacy of AMG 811, a Human Anti-Interferon- $\gamma$ Antibody, in Patients With Discoid Lupus Erythematosus. Arthritis Rheumatol. 2017, 69, 1028-1034. [CrossRef]

37. Cesaroni, M.; Seridi, L.; Loza, M.J.; Schreiter, J.; Sweet, K.; Franks, C.; Ma, K.; Orillion, A.; Campbell, K.; Gordon, R.M.; et al. Suppression of Serum Interferon- $\gamma$ Levels as a Potential Measure of Response to Ustekinumab Treatment in Patients With Systemic Lupus Erythematosus. Arthritis Rheumatol. 2021, 73, 472-477. [CrossRef]

38. Aggarwal, B.B.; Gupta, S.C.; Kim, J.H. Historical perspectives on tumor necrosis factor and its superfamily: 25 years later, a golden journey. Blood 2012, 119, 651-665. [CrossRef]

39. Cigni, A.; Pileri, P.V.; Faedda, R.; Gallo, P.; Sini, A.; Satta, A.E.; Marras, R.; Carta, E.; Argiolas, D.; Rum, I.; et al. Interleukin 1, interleukin 6, interleukin 10, and tumor necrosis factor $\alpha$ in active and quiescent systemic lupus erythematosus. J. Investig. Med. 2014, 62, 825-829. [CrossRef]

40. Idborg, H.; Eketjäll, S.; Pettersson, S.; Gustafsson, J.T.; Zickert, A.; Kvarnström, M.; Oke, V.; Jakobsson, P.-J.; Gunnarsson, I.; Svenungsson, E. TNF- $\alpha$ and plasma albumin as biomarkers of disease activity in systemic lupus erythematosus. Lupus Sci. Med. 2018, 5, e000260. [CrossRef] [PubMed]

41. Weckerle, C.E.; Mangale, D.; Franek, B.S.; Kelly, J.A.; Kumabe, M.; James, J.A.; Moser, K.L.; Harley, J.B.; Niewold, T.B. Large-scale analysis of tumor necrosis factor $\alpha$ levels in systemic lupus erythematosus. Arthritis Rheum. 2012, 64, 2947-2952. [CrossRef] [PubMed]

42. Barkauskaite, V.; Ek, M.; Popovic, K.; Harris, H.E.; Wahren-Herlenius, M.; Nyberg, F. Translocation of the novel cytokine HMGB1 to the cytoplasm and extracellular space coincides with the peak of clinical activity in experimentally UV-induced lesions of cutaneous lupus erythematosus. Lupus 2007, 16, 794-802. [CrossRef]

43. Zampieri, S.; Alaibac, M.; Iaccarino, L.; Rondinone, R.; Ghirardello, A.; Sarzi-Puttini, P.; Peserico, A.; Doria, A. Tumour necrosis factor alpha is expressed in refractory skin lesions from patients with subacute cutaneous lupus erythematosus. Ann. Rheum. Dis. 2006, 65, 545-548. [CrossRef] [PubMed]

44. De Bandt, M. Lessons for lupus from tumour necrosis factor blockade. Lupus 2006, 15, 762-767. [CrossRef] [PubMed]

45. Alves, P.; Bashir, M.M.; Wysocka, M.; Zeidi, M.; Feng, R.; Werth, V.P. Quinacrine Suppresses Tumor Necrosis Factor- $\alpha$ and IFN- $\alpha$ in Dermatomyositis and Cutaneous Lupus Erythematosus. J. Investig. Dermatol. Symp. Proc. 2017, 18, S57-S63. [CrossRef] [PubMed]

46. Sacre, K.; Criswell, L.A.; McCune, J.M. Hydroxychloroquine is associated with impaired interferon-alpha and tumor necrosis factor-alpha production by plasmacytoid dendritic cells in systemic lupus erythematosus. Arthritis Res. Ther. 2012, 14, R155. [CrossRef]

47. Hegazy, M.; Darwish, H.; Darweesh, H.; El-Shehaby, A.; Emad, Y. Raised serum level of APRIL in patients with systemic lupus erythematosus: Correlations with disease activity indices. Clin. Immunol. 2010, 135, 118-124. [CrossRef]

48. Boghdadi, G.; Elewa, E.A. Increased serum APRIL differentially correlates with distinct cytokine profiles and disease activity in systemic lupus erythematosus patients. Rheumatol. Int. 2014, 34, 1217-1223. [CrossRef]

49. Zhang, J.; Roschke, V.; Baker, K.P.; Wang, Z.; Alarcón, G.S.; Fessler, B.J.; Bastian, H.; Kimberly, R.P.; Zhou, T. Cutting edge: A role for B lymphocyte stimulator in systemic lupus erythematosus. J. Immunol. 2001, 166, 6-10. [CrossRef] 
50. Hay, E.M.; Bacon, P.A.; Gordon, C.; Isenberg, D.A.; Maddison, P.; Snaith, M.L.; Symmons, D.P.; Viner, N.; Zoma, A. The BILAG index: A reliable and valid instrument for measuring clinical disease activity in systemic lupus erythematosus. Q. J. Med. 1993, $86,447-458$.

51. Vincent, F.B.; Kandane-Rathnayake, R.; Hoi, A.Y.; Slavin, L.; Godsell, J.D.; Kitching, A.R.; Harris, J.; Nelson, C.L.; Jenkins, A.J.; Chrysostomou, A.; et al. Urinary B-cell-activating factor of the tumour necrosis factor family (BAFF) in systemic lupus erythematosus. Lupus 2018, 27, 2029-2040. [CrossRef]

52. Fanouriakis, A.; Tziolos, N.; Bertsias, G.; Boumpas, D.T. Update on the diagnosis and management of systemic lupus erythematosus. Ann. Rheum. Dis. 2021, 80, 14-25. [CrossRef]

53. Navarra, S.V.; Guzmán, R.M.; Gallacher, A.E.; Hall, S.; Levy, R.A.; Jimenez, R.E.; Li, E.K.-M.; Thomas, M.; Kim, H.-Y.; León, M.G.; et al. BLISS-52 Study Group Efficacy and safety of belimumab in patients with active systemic lupus erythematosus: A randomised, placebo-controlled, phase 3 trial. Lancet 2011, 377, 721-731. [CrossRef]

54. Furie, R.; Petri, M.; Zamani, O.; Cervera, R.; Wallace, D.J.; Tegzová, D.; Sánchez-Guerrero, J.; Schwarting, A.; Merrill, J.T.; Chatham, W.W.; et al. BLISS-76 Study Group A phase III, randomized, placebo-controlled study of belimumab, a monoclonal antibody that inhibits B lymphocyte stimulator, in patients with systemic lupus erythematosus. Arthritis Rheum. 2011, 63, 3918-3930. [CrossRef]

55. Dall'Era, M.; Chakravarty, E.; Wallace, D.; Genovese, M.; Weisman, M.; Kavanaugh, A.; Kalunian, K.; Dhar, P.; Vincent, E.; Pena-Rossi, C.; et al. Reduced B lymphocyte and immunoglobulin levels after atacicept treatment in patients with systemic lupus erythematosus: Results of a multicenter, phase Ib, double-blind, placebo-controlled, dose-escalating trial. Arthritis Rheum. 2007, 56, 4142-4150. [CrossRef]

56. Tocut, M.; Shoenfeld, Y.; Zandman-Goddard, G. Systemic lupus erythematosus: An expert insight into emerging therapy agents in preclinical and early clinical development. Expert Opin. Investig. Drugs 2020, 29, 1151-1162. [CrossRef] [PubMed]

57. Gordon, C.; Wofsy, D.; Wax, S.; Li, Y.; Pena-Rossi, C.; Isenberg, D. Post Hoc Analysis of the Phase II/III APRIL-SLE Study: Association Between Response to Atacicept and Serum Biomarkers Including BLyS and APRIL. Arthritis Rheumatol. 2017, 69, 122-130. [CrossRef] [PubMed]

58. Parodis, I.; Zickert, A.; Sundelin, B.; Axelsson, M.; Gerhardsson, J.; Svenungsson, E.; Malmström, V.; Gunnarsson, I. Evaluation of B lymphocyte stimulator and a proliferation inducing ligand as candidate biomarkers in lupus nephritis based on clinical and histopathological outcome following induction therapy. Lupus Sci. Med. 2015, 2, e000061. [CrossRef] [PubMed]

59. Liao, W.; Lin, J.-X.; Leonard, W.J. IL-2 family cytokines: New insights into the complex roles of IL-2 as a broad regulator of T helper cell differentiation. Curr. Opin. Immunol. 2011, 23, 598-604. [CrossRef] [PubMed]

60. Shao, M.; He, J.; Zhang, R.; Zhang, X.; Yang, Y.; Li, C.; Liu, X.; Sun, X.; Li, Z. Interleukin-2 Deficiency Associated with Renal Impairment in Systemic Lupus Erythematosus. J. Interferon Cytokine Res. 2019, 39, 117-124. [CrossRef]

61. Shao, M.; Sun, X.-L.; Sun, H.; He, J.; Zhang, R.-J.; Zhang, X.; Li, Z.-G. Clinical Relevance of Autoantibodies against Interleukin-2 in Patients with Systemic Lupus Erythematosus. Chin. Med. J. 2018, 131, 1520-1526. [CrossRef]

62. He, J.; Zhang, R.; Shao, M.; Zhao, X.; Miao, M.; Chen, J.; Liu, J.; Zhang, X.; Zhang, X.; Jin, Y.; et al. Efficacy and safety of low-dose IL-2 in the treatment of systemic lupus erythematosus: A randomised, double-blind, placebo-controlled trial. Ann. Rheum. Dis. 2020, 79, 141-149. [CrossRef] [PubMed]

63. Davis, L.S.; Hutcheson, J.; Mohan, C. The role of cytokines in the pathogenesis and treatment of systemic lupus erythematosus. J. Interferon Cytokine Res. 2011, 31, 781-789. [CrossRef] [PubMed]

64. Thanadetsuntorn, C.; Ngamjanyaporn, P.; Setthaudom, C.; Hodge, K.; Saengpiya, N.; Pisitkun, P. The model of circulating immune complexes and interleukin-6 improves the prediction of disease activity in systemic lupus erythematosus. Sci. Rep. 2018, 8, 2620. [CrossRef] [PubMed]

65. Su, H.; Lei, C.-T.; Zhang, C. Interleukin-6 Signaling Pathway and Its Role in Kidney Disease: An Update. Front. Immunol. 2017, 8, 405. [CrossRef] [PubMed]

66. Illei, G.G.; Shirota, Y.; Yarboro, C.H.; Daruwalla, J.; Tackey, E.; Takada, K.; Fleisher, T.; Balow, J.E.; Lipsky, P.E. Tocilizumab in systemic lupus erythematosus: Data on safety, preliminary efficacy, and impact on circulating plasma cells from an open-label phase I dosage-escalation study. Arthritis Rheum. 2010, 62, 542-552. [CrossRef]

67. Wallace, D.J.; Strand, V.; Merrill, J.T.; Popa, S.; Spindler, A.J.; Eimon, A.; Petri, M.; Smolen, J.S.; Wajdula, J.; Christensen, J.; et al. Efficacy and safety of an interleukin 6 monoclonal antibody for the treatment of systemic lupus erythematosus: A phase II dose-ranging randomised controlled trial. Ann. Rheum. Dis. 2017, 76, 534-542. [CrossRef] [PubMed]

68. Sharif, M.N.; Tassiulas, I.; Hu, Y.; Mecklenbräuker, I.; Tarakhovsky, A.; Ivashkiv, L.B. IFN-alpha priming results in a gain of proinflammatory function by IL-10: Implications for systemic lupus erythematosus pathogenesis. J. Immunol. 2004, 172, 6476-6481. [CrossRef] [PubMed]

69. Peng, H.; Wang, W.; Zhou, M.; Li, R.; Pan, H.-F.; Ye, D.-Q. Role of interleukin-10 and interleukin-10 receptor in systemic lupus erythematosus. Clin. Rheumatol. 2013, 32, 1255-1266. [CrossRef]

70. Llorente, L.; Richaud-Patin, Y.; García-Padilla, C.; Claret, E.; Jakez-Ocampo, J.; Cardiel, M.H.; Alcocer-Varela, J.; Grangeot-Keros, L.; Alarcón-Segovia, D.; Wijdenes, J.; et al. Clinical and biologic effects of anti-interleukin-10 monoclonal antibody administration in systemic lupus erythematosus. Arthritis Rheum. 2000, 43, 1790-1800. [CrossRef]

71. Klavdianou, K.; Lazarini, A.; Fanouriakis, A. Targeted Biologic Therapy for Systemic Lupus Erythematosus: Emerging Pathways and Drug Pipeline. BioDrugs 2020, 34, 133-147. [CrossRef] 
72. Ludwiczek, O.; Kaser, A.; Koch, R.O.; Vogel, W.; Cruikshank, W.W.; Tilg, H. Activation of caspase-3 by interferon alpha causes interleukin-16 secretion but fails to modulate activation induced cell death. Eur. Cytokine Netw. 2001, 12, 478-486.

73. Richmond, J.; Tuzova, M.; Cruikshank, W.; Center, D. Regulation of cellular processes by interleukin-16 in homeostasis and cancer. J. Cell. Physiol. 2014, 229, 139-147. [CrossRef]

74. Lard, L.R.; Roep, B.O.; Verburgh, C.A.; Zwinderman, A.H.; Huizinga, T.W.J. Elevated IL-16 levels in patients with systemic lupus erythematosus are associated with disease severity but not with genetic susceptibility to lupus. Lupus 2002, 11, 181-185. [CrossRef]

75. Niewold, T.B.; Meves, A.; Lehman, J.S.; Popovic-Silwerfeldt, K.; Häyry, A.; Söderlund-Matell, T.; Charlesworth, C.M.; Madden, B.; Lundberg, I.E.; Wahren-Herlenius, M.; et al. Proteome study of cutaneous lupus erythematosus (CLE) and dermatomyositis skin lesions reveals IL-16 is differentially upregulated in CLE. Arthritis Res. Ther. 2021, 23, 132. [CrossRef]

76. Amatya, N.; Garg, A.V.; Gaffen, S.L. IL-17 Signaling: The Yin and the Yang. Trends Immunol. 2017, 38, 310-322. [CrossRef] [PubMed]

77. Wolk, K.; Witte, K.; Witte, E.; Raftery, M.; Kokolakis, G.; Philipp, S.; Schönrich, G.; Warszawska, K.; Kirsch, S.; Prösch, S.; et al. IL-29 is produced by T(H)17 cells and mediates the cutaneous antiviral competence in psoriasis. Sci. Transl. Med. 2013, 5, $204 \mathrm{ra129.}$ [CrossRef] [PubMed]

78. Zickert, A.; Amoudruz, P.; Sundström, Y.; Rönnelid, J.; Malmström, V.; Gunnarsson, I. IL-17 and IL-23 in lupus nephritisassociation to histopathology and response to treatment. BMC Immunol. 2015, 16, 7. [CrossRef] [PubMed]

79. Hu, F.-Q.; Zhang, Y.-P.; Yin, J.; Tang, Z.-Q.; Han, Y.-F.; Shi, Z.-R.; Tan, G.-Z.; Wang, L. Characterization of autoantibodies and cytokines related to cutaneous lupus erythematosus. Lupus 2021, 30, 315-319. [CrossRef]

80. Tanasescu, C.; Balanescu, E.; Balanescu, P.; Olteanu, R.; Badea, C.; Grancea, C.; Vagu, C.; Bleotu, C.; Ardeleanu, C.; Georgescu, A. IL-17 in cutaneous lupus erythematosus. Eur. J. Intern. Med. 2010, 21, 202-207. [CrossRef] [PubMed]

81. Sippl, N.; Faustini, F.; Rönnelid, J.; Turcinov, S.; Chemin, K.; Gunnarsson, I.; Malmström, V. Arthritis in systemic lupus erythematosus is characterized by local IL-17A and IL-6 expression in synovial fluid. Clin. Exp. Immunol. 2021, 205 , 44-52. [CrossRef] [PubMed]

82. Mathias, L.M.; Stohl, W. Systemic lupus erythematosus (SLE): Emerging therapeutic targets. Expert Opin. Ther. Targets 2020, 24, 1283-1302. [CrossRef]

83. Van Vollenhoven, R.F.; Hahn, B.H.; Tsokos, G.C.; Wagner, C.L.; Lipsky, P.; Touma, Z.; Werth, V.P.; Gordon, R.M.; Zhou, B.; Hsu, B.; et al. Efficacy and safety of ustekinumab, an IL-12 and IL-23 inhibitor, in patients with active systemic lupus erythematosus: Results of a multicentre, double-blind, phase 2, randomised, controlled study. Lancet 2018, 392, 1330-1339. [CrossRef]

84. Kinoshita, K.; Yamagata, T.; Nozaki, Y.; Sugiyama, M.; Ikoma, S.; Funauchi, M.; Kanamaru, A. Blockade of IL-18 receptor signaling delays the onset of autoimmune disease in MRL-Faslpr mice. J. Immunol. 2004, 173, 5312-5318. [CrossRef]

85. Mende, R.; Vincent, F.B.; Kandane-Rathnayake, R.; Koelmeyer, R.; Lin, E.; Chang, J.; Hoi, A.Y.; Morand, E.F.; Harris, J.; Lang, T. Analysis of Serum Interleukin (IL)-1 $\beta$ and IL-18 in Systemic Lupus Erythematosus. Front. Immunol. 2018, 9, 1250. [CrossRef]

86. Wang, D.; Drenker, M.; Eiz-Vesper, B.; Werfel, T.; Wittmann, M. Evidence for a pathogenetic role of interleukin-18 in cutaneous lupus erythematosus. Arthritis Rheum. 2008, 58, 3205-3215. [CrossRef]

87. Xiang, M.; Feng, Y.; Wang, Y.; Wang, J.; Zhang, Z.; Liang, J.; Xu, J. Correlation between circulating interleukin-18 level and systemic lupus erythematosus: A meta-analysis. Sci. Rep. 2021, 11, 4707. [CrossRef]

88. Xu, W.-D.; Su, L.-C.; Liu, X.-Y.; Wang, J.-M.; Yuan, Z.-C.; Qin, Z.; Zhou, X.-P.; Huang, A.-F. IL-38: A novel cytokine in systemic lupus erythematosus pathogenesis. J. Cell. Mol. Med. 2020, 24, 12379-12389. [CrossRef] [PubMed]

89. Long, D.; Chen, Y.; Wu, H.; Zhao, M.; Lu, Q. Clinical significance and immunobiology of IL-21 in autoimmunity. J. Autoimmun. 2019, 99, 1-14. [CrossRef] [PubMed]

90. Nakou, M.; Papadimitraki, E.D.; Fanouriakis, A.; Bertsias, G.K.; Choulaki, C.; Goulidaki, N.; Sidiropoulos, P.; Boumpas, D.T. Interleukin-21 is increased in active systemic lupus erythematosus patients and contributes to the generation of plasma B cells. Clin. Exp. Rheumatol. 2013, 31, 172-179.

91. Pan, H.-F.; Wu, G.-C.; Fan, Y.-G.; Leng, R.-X.; Peng, H.; Zhou, M.; Li, B.-Z.; Zhu, Y.; Tao, J.-H.; Li, X.-P.; et al. Decreased serum level of IL-21 in new-onset systemic lupus erythematosus patients. Rheumatol. Int. 2013, 33, 2337-2342. [CrossRef] [PubMed]

92. Wang, S.; Wang, J.; Kumar, V.; Karnell, J.L.; Naiman, B.; Gross, P.S.; Rahman, S.; Zerrouki, K.; Hanna, R.; Morehouse, C.; et al. IL-21 drives expansion and plasma cell differentiation of autoreactive CD11c ${ }^{\text {hi }}$ T-bet ${ }^{+}$B cells in SLE. Nat. Commun. 2018, 9, 1758. [CrossRef] 